\title{
Extensionist experience of undergraduate students in medicine as part of the Mais Médicos para o Brasil [more doctors for Brazil] program
}

Experiência extensionista de estudantes de graduação em medicina inseridos no programa Mais Médicos para o Brasil

Experiencia extensionista de estudiantes de graduación en medicina como parte del programa Mais Médicos para o Brasil

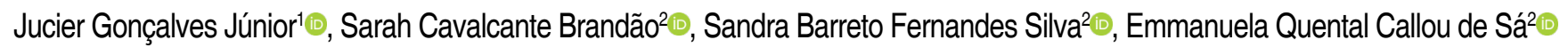
${ }^{1}$ Faculdade de Medicina, Departamento de Reumatologia - Universidade de São Paulo (USP), São Paulo

${ }^{2}$ Faculdade de Medicina - Universidade Federal do Cariri

\begin{abstract}
Problem: The new National Curriculum Guidelines of Undergraduate Medicine in Brazil propose that academics have contact with the health system and its users at an early stage. However, practical activities in undergraduate courses proved to be insufficient for the adequate development of this new perspective. Consequently, the experiences of university extension have the proposal to fill in this gap. Method: This article aimed to report the experiences of the scholarship holders of the Extension Project in Family and Community Medicine - ProMFC (Projeto de Extensão em Medicina de Família e Comunidade) under the More Doctors for Brazil Program - PMMB (Programa Mais Médicos para o Brasil). This is a qualitative, experience-type study with lexical and content analysis from the software IRaMutTeQ, version 0.7 alpha 2, to establish an association between the terms used in the discourse of the ProMFC. Results: The opportunity to immerse in environments in which students can learn about the problems and share the daily life of the assisted community was highlighted. The exchange of knowledge and experiences among students, physicians working in Primary Health Care (fellows of the PMMB, supervisors and tutors) and local managers was also relevant, as well as the students' ability to develop/train skills, such as teamwork, assertive communication, and health planning. Conclusion: The PMMB, tutored and integrated into an extension project, the ProMFC, is an alternative that, although embryonic, has many potentialities, as it allows the extensionists to be early inserted into the Attention Primary Health Care.
\end{abstract}

Keywords: Primary Health Care; More Medical Program for Brazil; Health Education.

Como citar: Gonçalves Júnior J, Brandão SC, Silva SBF, Sá EQC .Extensionist experience of undergraduate students in medicine as part of the mais médicos para o Brasil [more doctors for brazil] program. Rev Bras Med Fam Comunidade. 2021;16(43):2528. https://doi.org/10.5712/rbmfc16(43)2528

\author{
Corresponding author: \\ Jucier Gonçalves Júnior. \\ E-mail: \\ juciergjunior@hotmail.com \\ Funding: \\ No external funding. \\ Ethical approval: \\ CEP-UFCA: \\ 58205216.7.0000.5698 \\ Provenance: \\ Not comissioned. \\ Peer review: \\ External. \\ Received:18/05/2020. \\ Accepted: 6/02/2021.
}




\section{Resumo}

Problema: As novas Diretrizes Curriculares Nacionais de Graduação em Medicina no Brasil propõem que os acadêmicos tenham contato com o sistema de saúde e seus usuários de forma precoce. No entanto, as atividades práticas na graduação mostraram-se insuficientes para o desenvolvimento adequado dessa nova perspectiva. Por conseguinte, as experiências de extensão universitária têm a proposta de preencher essa lacuna. Método: Este artigo objetivou relatar as experiências vivenciadas pelos bolsistas do Projeto de Extensão em Medicina de Família e Comunidade (ProMFC) no âmbito do Programa Mais Médicos para o Brasil (PMMB). Trata-se de estudo qualitativo, do tipo relato de experiência, com análise léxica e de conteúdo a partir do software IRaMutTeQ, versão 0.7 alpha 2, para estabelecer associação entre termos usados no discurso dos bolsistas do ProMFC. Resultados: Destacou-se a oportunidade de imersão em ambientes nos quais os estudantes podem conhecer as problemáticas e compartilhar o cotidiano da comunidade assistida. A troca de saberes e experiências entre estudantes, médicos atuantes na Atenção Primária à Saúde (bolsistas do PMMB, supervisores e tutores), e gestores locais também foi relevante, assim como a possibilidade de os alunos desenvolverem/treinarem habilidades, como trabalho em equipe, comunicação assertiva e planejamento em saúde. Conclusão: O PMMB, tutorado e integrado a um projeto de extensão, o Projeto de Extensão em Medicina de Família e Comunidade, mostrouse como alternativa que, embora embrionária, tem inúmeras potencialidades, à medida que oportuniza aos extensionistas a inserção precoce na Atenção Primária à Saúde.

Palavras-chave: Atenção Primária à Saúde; Programa Mais Médicos para o Brasil Recursos Humanos; Educação em Saúde.

\section{Resumen}

Problema:Las nuevas Directrices Curriculares Nacionales para Medicina de Pregrado en Brasil proponen que los académicos tengan contacto con el sistema de salud y sus usuarios en una etapa temprana. Sin embargo, las actividades prácticas en los cursos de pregrado resultaron ser insuficientes para el desarrollo adecuado de esta nueva perspectiva. En consecuencia, las experiencias en extensión universitaria tienen el propósito de llenar este vacío. Método: Este artículo tuvo como objetivo informar las experiencias vividas por los académicos del Proyecto de Extensión en Medicina Familiar y Comunitaria - ProMFC (Programa Mais Médicos para o Brasi) en el ámbito del Programa Más Médicos para Brasil - PMMB (Programa Mais Médicos para o Brasil). Este es un estudio cualitativo, del tipo informe de experiencia, con análisis de léxico y contenido utilizando el software IRaMutTeQ, versión 0.7 alpha 2 , para establecer asociación entre los términos utilizados en el discurso de los becarios del ProMFC. Resultados: Se destacó la oportunidad de inmersión en entornos en los que los estudiantes pueden saber sobre los problemas y compartir la vida diaria de la comunidad asistida. El intercambio de conocimientos y experiencias entre estudiantes, médicos que trabajan en la Atención Primaria de Salud (becarios del PMMB, supervisor y tutores) y gerentes locales también fue relevante, así como la posibilidad de que los estudiantes desarrollen/capaciten habilidades, como trabajar en equipo, comunicación asertiva y planificación de la salud. Conclusión: EI PMMB, tutorizado e integrado en un proyecto de extensión, el ProFMC, demostró ser una alternativa que, aunque embrionaria, tiene numerosos potenciales, ya que brinda a los extensionistas la oportunidad de inserción temprana en Atención Primaria de Salud.

Palabras clave: Atención Primaria de Salud; Programa Más Médicos para Brasil; Educación en Salud.

\section{INTRODUCTION}

After 32 years since the creation of the Single Health System (Sistema Único de Saúde - SUS), public health in Brazil is experiencing one of the most challenging periods. Immersed in tensions in the political and economic scenarios, the system has suffered from successive budget cuts and substantial changes in the shaping of health policies. ${ }^{1}$

The scarcity and poor distribution of the qualified workforce are global concerns, but developing countries are especially affected. This standard limits the accessibility to health services in rural and remote areas. ${ }^{2,3}$ In fact, the qualified construction of SUS requires significant investments not only in the structuring of services and in the distribution of health professionals, but also in their training, valuation and establishment.

Furthermore, there is a historical gap in the training process of health professionals. Thus, it is necessary to deeply reflect on the epistemological assumptions in health, which must be based on social determinants, the needs of the population and the locoregional epidemiological profile. ${ }^{4}$

Due to the demand of the health system and users for a more humanized medicine and not focused only on pathology, there is a global collective effort to propose changes in the biomedical, curative health model for a holistic, biopsychosocial and integral approach, evidencing a health education centered not only on technical skills, but also on humanized care.$^{5,6,7}$ In Brazil, this reality comes to fruition with the proposal of the new National Curriculum Guidelines for Undergraduate Students of Medicine in Brazil, which proposes a professional with humanized, critical and reflective training, able to work at the SUS. ${ }^{8}$ 
However, despite the new curricular guidelines, practical activities in undergraduate courses still proved to be insufficient for the adequate development of the necessary competences for medical practice. Consequently, the experiences of university extension come to supply this lack of medical training focused on the biopsychosocial model. ${ }^{9}$

Among the government actions to qualify training for SUS, the More Doctors Program for Brazil (Programa Mais Médicos para o Brasil - PMMB) was created. It is a public health policy, supported by Law No. 12,871 , as of October $22,2013,{ }^{10}$ intersectoral, the purpose of which is to expand the practice and the insertion of the doctors in training at the SUS care units at an early stage, in strengthening training-service integration, with academic supervision executed by higher education institutions and in the exchange of knowledge and experiences between professionals and students. ${ }^{9}$ This measure was implemented in order to address both the problems of deficit in the supply of professionals for the SUS staff and the change in the current medical training model.

The PMMB, tutored by a public university in the countryside of the State of Ceará, Brazil, after five years of existence, added to its functioning an extension project - Extension Project in Family and Community Medicine (Projeto de Extensão em Medicina de Família e Comunidade - ProMFC), aiming at the early insertion of students into the Primary Health Care (PHC), as well as promoting real experiences at the SUS, under the seal of tutors of the PMMB in partnership with professors in the disciplines of Basic Health Care (Assistência Básica à Saúde - ABS), discipline of basic studies in attention and health promotion in the medical course in Brazil.

The project was created in 2017, being guided by three professors, two PhDs (Medical Sciences and Primary Care) and one Anesthesiologist (Pain Specialist/ Primary Care). It included 12 undergraduate medical students. Its actions focused on three axes: (I) Health Promotion Activities - organization of lectures on topics relevant to local public health; internships in Basic Health Units (UBS) linked to the PMMB; (II) Activities in Research and Continued Education - preparation of case reports, literature reviews and cross-sectional studies based on the students' experiences in the internships; participation of classes promoted by the PMMB on the main themes of primary care, with medical preceptors / professors from the regulating HEI (III) Management Activities - assistance in the logistical preparation of the PMMB locoregional workshops, as well as participation in meetings with managers of the 34 municipalities linked to the program. This prerogative was thought of when it was perceived that the practice of medicine has changed and demands new professional skills, consequently requiring adjustments to the training process offered by medical schools. ${ }^{11-13}$

Thus, the purpose was to report the experiences lived by the ProMFC fellows within the scope of the PMMB.

\section{METHODS}

\section{Study design:}

Unique qualitative case study, of the experience report type, using lexical and content analysis. Participants were selected for convenience, using the following inclusion criteria: being medical students at a public Higher Education Institution, in the center-south region of the countryside of the state of Ceará; having participated in the ProMFC during the year of 2017. All eight students/fellows accepted to participate in the research. 


\section{Data Collection}

Data collection took place in December 2017, at the last ProMFC articulation meeting. At the time, students were asked to answer two questions:

A. What were the negative points and / or challenges faced during the project's year of operation?

B. What were the positive points and / or gains obtained during the project's year of operation?

The discussion was carried out in the Yarning Circle format and recorded in the Minutes of the Meetings. In the end, the portfolio was indicated with the main conclusions of the activity. The responses of each student were extracted from the portfolio and the Minutes and tabulated into the Microsoft Word $\AA$ program saved in Rich Text format. To maintain anonymity, each student was designated by the letter "E" followed by a number from 1 to 8 during the analysis of the material. The Text Units were organized in the same textual corpus and submitted to lexical analysis by the Iramuteq software. This software is an Interface of $R$ for Multidimensional Text and Questionnaire Analyzes (Interface of R pour les Analyses Multidimensionnelles de Textes et de Questionnaires - IraMuTeQ) version 0.7 alpha 2 developed by Pierre Ratinaud, which allows to make statistical analyzes about textual corpus and individuals/words tables. ${ }^{14}$

The analysis was performed in two stages. Firstly, the students' speeches were organized and summarized by type of events and/or activities developed throughout the year. For heuristic reasons, we have organized the information into three main themes: (a) Management Activities, Organization and Planning; (b) Health Education Activities, Campaigns and Supervised Internship in Primary Health Care; (c) Theoretical and Research Activities.

Before starting the analysis in the parameterization of the text segments, only "full" language elements were selected to be considered by the software in the lexical analysis (adjectives, unrecognized forms, nouns and verbs) and those auxiliary nouns and verbs as complementary (supplementary), aiming to value the contents of the evaluated text by means of similarity analysis.

\section{Ethics:}

The work followed the ethical precepts agreed to in the declaration of Helsinki and the regulatory standard 510/2016 of the National Health Council (Conselho Nacional de Saúde - CNS), the instance of the SUS with the mission of inspecting, accompanying and monitoring public health policies, ${ }^{13}$ being approved by the Human Research Ethics Committee (Comitê de Ética em Pesquisa com Seres Humanos - CEP), an interdisciplinary collegiate created to contribute to the development of research within ethical standards, ${ }^{14}$ under number 58205216.7.0000.5698.

\section{RESULTS}

In chart 1, among the students' impressions about the activities practiced by the ProMFC in 2017, the opportunity to immerse themselves into environments in which they can identify and share the community's concerns, doubts, daily life and ways of experiencing reality is highlighted. The knowledge and experiences exchanged between students and doctors working in PHC (PMMB fellows and tutors) and local managers built the possibility of training skills such as: teamwork, assertive communication and work organization when planning and executing, under supervision, large events, and assisting in the PMMB locoregional workshops. 
Chart 1. Description of the activities performed, and the results achieved in the view of the fellows of the ProMFC.

\begin{tabular}{|c|c|}
\hline \multicolumn{2}{|r|}{ Management Activities, Organization and Planning } \\
\hline $\begin{array}{l}\text { Description of the } \\
\text { activity performed }\end{array}$ & $\begin{array}{l}\text { - Contribution to the execution of Locoregional Meetings promoted by the Mentoring with support of the } \\
\text { supervision from the PMMB of the medicine college. } \\
\text { Periodic evaluative and training meetings } \\
\text { Support to the PMMB at the reception of the Cuban entourage to Brazil. } \\
\text { Carrying out of the } 1^{\text {st }} \text { Simpósio de Humanização em Saúde (Humanization of in Health Symposium): from } \\
\text { patient to caregiver in partnership with other extension programs of the university. }\end{array}$ \\
\hline $\begin{array}{l}\text { Desc } \\
\text { resul }\end{array}$ & $\begin{array}{l}\text { - Allowing the debate and planning in the future actions and reflections about management promoted by ProMFC. } \\
\text { Possibility of exchanging experiences and knowledge with the Cuban doctors (fifty in number) who take part } \\
\text { in the PMMB and with the health secretaries of the region who attended the symposium. } \\
\text { Notions of articulation, teamwork and assertive communication in the elaboration of the event. }\end{array}$ \\
\hline $\begin{array}{l}\text { Spee } \\
\text { the ex }\end{array}$ & $\begin{array}{l}\text { - "In addition to following the classes and theoretical activities of the [PMMB] program, we had the opportunity } \\
\text { to train the organization and execution of a medium-sized event" (E2) } \\
\text { "The symposium was good, because it is a yet little discussed topic" (E3) } \\
\text { "In the locoregional workshops, it was also very good for us to be able to talk to city managers, see what they think, } \\
\text { how they are considering the program and the extension project, and we even received compliments" (E5) } \\
\text { "It was good because we saw the difficulty of working as a team and learning together. [...]" (E6) } \\
\text { "The best part is being able to talk to the scholarship doctors and see another view of the ABS that we have }\end{array}$ \\
\hline
\end{tabular}
in college. Like, it is the view of who is acting now, at the moment" (E8)

Health Education Activities, Campaigns and Supervised Internship in Primary Health Care

- $\quad$ Execution of health education actions on relevant topics to the Primary Care.

Participation in practical activities, in a supervised internship format at partners Basic Health Units, in the

Description of the activity performed . municipalities of the Metropolitan Region of Cariri.

Participation in a prevention campaign about sexually transmitted diseases and traffic safety, in partnership with the Municipal Health Secretariat.

Action on health education in a rural community, in partnership with other programs of the university.

- $\quad$ Strengthening of the ties of the teaching-service-community integration.

Description of the results achieved

Speeches about the experiences Expansion of the relationship with the reality of Primary Attention, through the insertion into the daily life of a health team and Basic Health Unit.

- It made close contact between the members of the project and the population of the region possible, thus allowing to broaden the vision of the fellows in relation to the themes.

- $\quad$ "In the home visits we made during the internship, we strengthened, as our advisor says a lot, the ties of the teaching-service-community integration" (E6).

"There was a great exchange of knowledge and the identification of the customs of the community" (E7)

- "Home visits also allowed our doubts to be resolved and we were able to have contact with the reality of the public that we will attend to in the future as health professionals" (E8)

- $\quad$ "The activities in the center of Barbalha in the campaign to prevent sexually transmitted diseases allowed us to have more contact with the population of the region. It also allowed us to broaden our view on the subject, as we had to study to inform correctly." (E1)

"It was really cool; the elderly were very receptive to the campaign and often approached us to ask for the kits we were distributing" (E2)

\section{Theoretical and Research Activities}

- Participation in formative classes with the work process in Basic Attention as the theme, in the same discussion environment with the supervisors.

Description of the activity performed

-

Collection, tabulation and analysis of data from the Projeto de Pesquisa Guarda-Chuva (Umbrella Research Project), inserted into the PMMB.

Presentation of scientific papers at local, regional and national events.

- $\quad$ Strengthening of competences, skills and attitudes about recurrent themes in Primary Care, with a better

Description of the results achieved

Speeches about the experiences understanding of the health-disease-care process.

- It provided us with the opportunity to participate in research projects; experience the elaboration of works and having contact with other researchers in events with themes aligned with the ProMFC purposes.

- $\quad$ "It enriched us a lot. Often the doctor needs to be a leader, and, in these cases, he/she needs to know how to organize actions in the health center and must take part in campaigns... This learning with the workshops made us aware of a lot in this sense" (E4)

"Training classes focused on Primary Care themes enriched us a lot and made us see the need to learn about recurring and relevant problems for the performance of professionals in a community" (E6)

- $\quad$ "In addition, we were able to participate in a large research project, which made us understand some things better, such as the integrating teaching with the service; on the other hand, it was also very difficult to collect the data" (E3) 
In data processing, the corpus consisted of 12 Initial Context Units (ICU) and 16-word segments. From the analysis of the graph theory (Figure 1), it was possible to identify the occurrences between words, helping to understand the structure of the content of a textual corpus. When analyzing students' speeches about the ProMFC activities, the correlation between the words "event", "planning and learning"; "health and enable", "scholarship and region"; "community", "experience", "to know" and "to perceive".

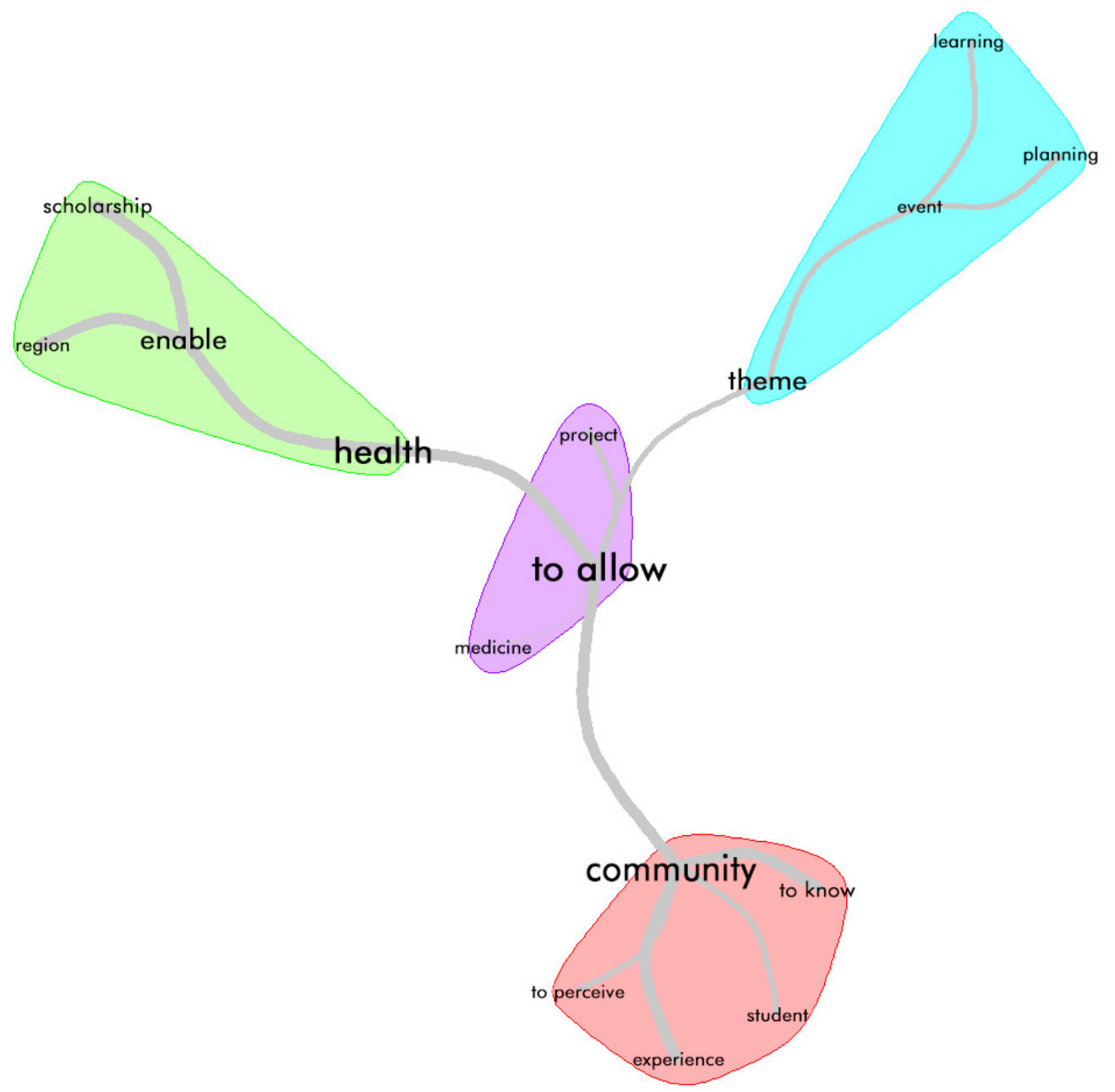

Figure 1. Similarity Dendrogram for students' activities in the ProMFC during the year of 2017.

\section{DISCUSSION}

We observed that the evoked words that constitute a correlation of similarity were event, planning and learning (Figure 1). Probably, they refer to the planning practices carried out by the academics in the elaboration of the events, articulation meetings and locoregional workshops of the PMMB, enabling them to entice a different knowledge than the one offered by the teaching staff of the academy. In addition, the academics participating in the Pro-MFC were able to follow changes in the organizational culture, with professional development activities in management and team building.

Universities must prepare students to learn teamwork, community action, agility, leadership and purposeful abilities. Likewise, it is known that the performance of medical activities in complex health systems 
requires the doctor to have knowledge and skills related to improving quality aimed at the population's health. ${ }^{17,18}$ The national curricular guidelines of the undergraduate medical course point out that the medical professional must be able to develop preventive, promotion, protection and rehabilitation health actions, both at the individual and the collective levels. ${ }^{19}$

Medical education plays a vital role in the knowledge of medical students and the provision of future health workers. ${ }^{2}$ Nevertheless, undergraduation still does not adequately prepare the undergraduates of the Medicine course to work in the Primary Health Care. ${ }^{20}$ Because, when the training process of professionals to act in the SUS fails, it fails in comply with one of its basic principles: comprehensiveness. In medical education, this proposition configures not only the technical excellence of training, but, above all, the care with the social relevance of medicine, giving rise to a curricular proposal to interconnect different areas of knowledge when considering the humanization, the ethics, the social control and the research as necessary for medical training and individual medical care. ${ }^{21}$

The similarity analysis (Figure 1) shows a correlation between the words know, perceive and experience; associated with "health", "enable and scholarship"; "theme", "learning and planning"; and all directly correlated to the word "project". The use of the ProMFC inserted into the PMMB as a tool that provides health education, reflects the reality of Extension as an agent capable of complementing medical training ${ }^{22}$ as it promotes insertion into the everyday, political, social and economic realities, in addition to the direct participation in the experiences with the community in which it is inserted, creating a cycle of social transformation. ${ }^{23,24}$

However, there is an increasing accumulation of scientific knowledge, often not associated with the development of skills that require critical and reflective reasoning and ethical and citizen behavior.

In this context, extension activities created an opportune and fruitful ground for good learning practices in $\mathrm{PHC}$, as they integrated, in the students, the notions of social participation, collective thinking and teamwork. The acting of students participating in the ProMFC encouraged the successful collaboration of the entire team, trained students in skills beyond techniques and improved the usage of relevant and varied resources. In addition, in these practice locations, students faced less competition from other students, playing a more significant role in the evaluation of patients, especially in the early stages of diseases and conditions.

The available evidence allows us to state that the PMMB has achieved a set of important results in changing medical training. In a research that analyzed the impact of the creation of medical courses supported by the PMMB in the countryside, the social representations about the work in the PHC of students were compared in the new courses and in the traditional courses. There was emphasis on the evocation of words such as "responsibility", "bond", "community" and "care". In the traditional courses, the most prominent terms were "devalued" and "precariousness", thus, it is possible to verify that the social representations of medical students in the new schools are more consistent with the PHC guidelines. ${ }^{25}$ Therefore, it is possible to notice that the words evoked by the academics of the new courses are consistent with the words evoked by the students participating in the ProMFC.

Furthermore, when the words "to know", "to perceive" and "experience" are evoked in the speeches, associated with "health", "enable" and "scholarship", it is inferred that they refer both to the activities in the Basic Health Unit linked to the PMMB, as well as in the campaigns performed throughout the year, such as campaigns for the prevention of Sexually Transmitted Diseases; Traffic Safety; suicide prevention; the 
activities in the rural community and the supervised internship in Family and Community Medicine that took place in three Basic Health Units in the region. This particularity denotes the social role of the ProMFC in the transformation of academics and their conceptions.

The literature states that the choice of the target audience based on local needs, as well as a good understanding of primary care and its functioning, is an integral part in the search for community action with social impact. Strengthening the understanding of primary care is central to improving the health care and health itself. ${ }^{26}$ Due to these new processes, the possibility of concrete changes in health practices emerges, with a view to the qualification of the health system, from professionals able to understand and intervene ${ }^{27}$ in existing demands and problems, both in primary, secondary and tertiary care. ${ }^{28}$

Another relevant factor is the opportunity of establishing contact and exchanging experiences between students and doctors working in the PHC (PMMB fellows, supervisors and tutors) and local managers, which are perceived from the correlation between the words evoked - "planning", "theme" and "event" (Figure 1 and Table 1). Extracurricular activities concur as collaborators of the integration between academy-service and public health. According to Machado and Ximenes ${ }^{4}$, the acting in primary care, especially in the $\mathrm{PHC}$, requires a diversity of knowledge and practices in areas related to management, care, management of social determinations and consequences and the territory of operation. In this sense, the early insertion of academics in health education activities is essential - both to acquire knowledge and to develop the needed skills in the future. ${ }^{29}$

Through the evocation of the words "scholarship", "region" and "enable", another aspect to be addressed is the low interest of both academics and professionals in more deprived and remote areas. The PMMB's proposal has the capacity to train professionals in line with the management and care model recommended by the System, calling for a different way of thinking about medical training.

Exposing medical students to experiences in rural communities, in order to positively influence the attraction to work in these areas after graduation, was an initiative of the World Health Organization (WHO), which in 2010 proposed a series of recommendations in response to the insufficiency of health workers in more remote and underserved areas. ${ }^{23,30} \mathrm{~A}$ large number of medical schools in many countries have implemented the strategy and many students have reported increased interest in working in this areas, thus demonstrating that it is possible to unite curriculum making and social impact. ${ }^{31,32,33}$

Research in different countries suggests that interventions with undergraduates can help. There is evidence that when academics are trained in practice fields in these areas, they are more likely to return to work in them. The difficulties in engaging and retaining doctors in these areas compromise the quality and access to healthcare. ${ }^{34,35,36}$ In addition, Zhang et al demonstrated in a cross-sectional survey on community health reform in China that students' perceptions of work in communities seem to influence their career choice. ${ }^{37}$ Thus, it can be understood that measures such as those offered by the ProMFC presented in this article have positive impacts.

As weaknesses of this work, we can mention the absence of sufficient text segments to carry out the descending Hierarchical Classification and quantitative analysis of the speeches.

The ProMFC, tutored and integrated into an extension project, shows itself as an alternative that, although embryonic, has innumerable potentials, as it gives extension workers an early insertion into the PHC, thus allowing students to experience the daily life of a community, facing real impasses in the elaboration, 
organization and execution of events/activities; training teamwork, assertive communication and group articulation skills; encouraging scientific research; bringing the university closer to local administrations, promoting a dialogical space of building mutual knowledge and benefits; and fomenting an integral view of the student, guiding their perspectives from a disease-centered care to a person-centered care, thus approaching the medical training of those recommended by international guidelines.

\section{CONCLUSION}

The ProFMC, in its first year of operation, provided an opportunity for the academics to apply the knowledge acquired during their undergraduation and the development of skills and fundamental attitudes for professionals working at the SUS. In accordance with the basic principles of the University Extension, the project instigates the integration of the activities of the University - PMMB.

The experiences raised during the ProFMC can be pilot models for improving teaching through active methodologies in Primary Care, since the teaching process needs experiences in real controlled environments that are conducive to learning. This raises a situation favorable to the deepening of teachingservice relationships at the SUS, based on the formulation of competent and active human materials in primary care.

\section{ACKNOWLEDGMENT}

The authors are grateful to the Ministry of Health and the Programa Mais Médicos para o Brasil (PMMB), in addition to the Universidade Federal do Cariri (UFCA) - School of Medicine for the logistical support.

\section{Conflict of Interest}

The author declare no conflict of interest.

\section{Author Contributions}

All authors prepared the review, developed the inclusion criteria, selected titles and abstracts, evaluated the quality of the articles included, and wrote the manuscript.

\section{REFERENCES}

1. Lazarini WS, Sodré, F. O SUS e as políticas sociais: Desafios contemporâneos para a atenção primária à saúde. Revista Brasileira de Medicina de Família e Comunidade 2019; 14(41): 1904. Portuguese. DOI: https://doi.org/10.5712/rbmfc14(41)1904

2. Liu J, Zhu B, Mao Y. Association between rural clinical clerkship and medical students' intentions to choose rural medical work after graduation: A cross-sectional study in Western China. PloS one 2018; 13(4). PMID: 29608624 DOI: https://doi.org/10.1371/journal. pone.0195266

3. Zhu B, Hsieh CW, Mao Y. Addressing the Licensed Doctor Maldistribution in China: A Demand-And-Supply Perspective. International journal of environmental research and public health 2019; 16(10): 1753. PMID: 31108920 DOI: https://doi.org/10.3390/ijerph16101753

4. Machado MH, Ximenes Neto FRG. Gestão da Educação e do Trabalho em Saúde no SUS: trinta anos de avanços e desafios. Ciência \& Saúde Coletiva 2018;23: 1971-1979. Portuguese. DOI: https://doi.org/10.1590/1413-81232018236.06682018

5. Kaluf IDO, Sousa SGO, Luz S, Cesario RR. Sentimentos do Estudante de Medicina quando em Contato com a Prática. Revista Brasileira de Educação Médica 2019; 43(1): 13-22. Portuguese. DOl: https://doi.org/10.1590/1981-52712015v43n1rb20180098 
6. Lurie N, Fremont A. Building bridges between medical care and public health. Jama 2019; 302(1): 84-86. DOI: https://doi.org/10.1001/ jama.2009.959

7. George E, Engel L. The clinical application of the biopsychosocial model. American Journal of Psychiatry 1980; 137(5): 535-544. DOI: https://doi.org/10.1176/ajp.137.5.535

8. Ministério da Educação do Brasil, resolução $n^{0}$ 3, de 20 de junho de 2014 [Internet]. Institui Diretrizes Curriculares Nacionais do Curso de Graduação em Medicina e de outras providências [mentioned as of May 12, 2020]. Available from: http://portal.mec.gov.br/index. php?option=com_docman\&view=download\&alias=15874-rces003-14\&category_slug=junho-2014-pdf\&ltemid=30192. Portuguese.

9. Matias MCS. O desafio ético-estético-político do SUS para a formação médica: uma análise do Programa Mais Médicos [Internet]. Brasil: Tese de Doutorado, Universidade Federal de Santa Catarina, Florianópolis, 2017 [mentioned as of May 12, 2020]; Available from: https:// repositorio.ufsc.br/bitstream/handle/123456789/189123/PGSC0203-T.pdf?sequence=-1\&isAllowed=y. Portuguese.

10. Lima SVMA, Nunes J, Santos L, Silva G, Melo H, Chaves S. O programa mais médicos e a atenção básica no Brasil: uma revisão integrativa. Gestão e Sociedade 2017; 11(30): 1963-1975. Portuguese. DOI: https://doi.org/10.21171/ges.v11i30.2216

11. Tempski PZ. Qualidade de Vida e Resiliência do Estudante de Medicina e da Escola Médica [Internet]. Brasil: Tese de Doutorado, Universidade de São Paulo, São Paulo, 2018 [mentioned as of May 12, 2020]; Available from: http://www.fm.usp.br/cedem/conteudo/ publicacoes/Qualidade_de_Vida_e_Resiliencia_do_Estudante_de_Medicina_e_da_Escola_Medica-compressed.pdf. Portuguese.

12. Gonçalves Júnior J et al. Programa Mais Médicos: Analysis of the Impressions of the Actors Involved in Brazil. Journal of family medicine \& community health. 2020; 7:1173-9.

13. Gonçalves Júnior J, Brandão SC, Silva SBF, Sá EQC. Rev Bras Med Famil Comunid 2020; 15(42):2526-2531.

14. Mendes FRP, Zangão MOB, Gemito MLGP, Serra ICC. Social Representations of nursing students about hospital assistance and primary health care. Revista Brasileira de Enfermagem 2016; 69(2): 321-8.

15. Brasil, resolução no 510, de 7 de abril de 2016 [Internet]. Ética na Pesquisa na área de Ciências Humanas e Sociais: conquista dos pesquisadores [mentioned as of May 12, 2020]. Available from: https://conselho.saude.gov.br/resolucoes/2016/Reso510.pdf. Portuguese.

16. Brasil, Resolução no 466, de 12 de dezembro de 2012 [Internet]. Conselho Nacional de Saúde [mentioned as of May 12, 2020]. Available from: https://www.conselho.saude.gov.br/resolucoes/2012/Reso466.pdf. Portuguese.

17. Amorim LM, Júnior JG, Rolim-Neto ML. Ensaio sobre a educação médica brasileira frente às vantagens e desvantagens do problembased learning (PBL). Revista E-Ciência 2017; 5(1). Portuguese. DOI: https://doi.org/10.19095/rec.v5i1.195

18. Lucey CR. Medical education: part of the problem and part of the solution. JAMA internal medicine 2013; 173(17): 1639-1643. PMID: 23857567 DOI: https://doi.org/10.1001/jamainternmed.2013.9074

19. Farias LABG. Estudantes de medicina e ação comunitária: estamos no caminho certo? Revista Brasileira de Medicina de Família e Comunidade 2017; 12(39): 1-2. Portuguese. DOI: https://doi.org/10.5712/rbmfc12(39)1640

20. Pinto HA, Andreazza R, Ribeiro RJ, Loula MR, Reis AACD. O Programa Mais Médicos e a mudança do papel do Estado na regulação e ordenação da formação médica. Interface-Comunicação, Saúde, Educação 2019;23:e170960. Portuguese. DOI: https://doi.org/10.1590/ interface.190003

21. Dias MMDS, Carvalho JLD, Landim LOP, Carneiro C. A Integralidade em Saúde na Educação Médica no Brasil: o Estado da Questão. Revista Brasileira de Educação Médica 2018;42(4): 123-133. Portuguese. DOI: https://doi.org/10.1590/1981-52712015v42n4rb20180094

22. Fórum de Pró-Reitores de Extensão das Universidades Públicas Brasileiras [Internet]. Política nacional de extensão universitária, 2012 [mentioned as of May 12, 2020]. Available from: http://portal.mec.gov.br/docman/setembro-2018-pdf/95681-texto-referencia-audienciapublica-diretrizes-politica-de-extensao/file. Portuguese.

23. Ribeiro MRF, de Araújo Pontes VM, Silva EA. A contribuição da extensão universitária na formação acadêmica: desafios e perspectivas. Revista Conexão UEPG 2017; 13(1): 52-65. Portuguese. DOI: https://doi.org/10.5212/Rev.Conexao.v.13.i1.0004

24. Arantes AR, Deslandes MS. A extensão universitária como meio de transformação social e profissional. Sinapse Múltipla 2017; 6(2): 179-183. Portuguese.

25. Santos WD, Comes Y, Pereira LL, Costa AM, Merchan-Hamann E, Santos LMP. Evaluation of the More Doctors Program: experience report. Saúde em Debate 2019; 43: 256-268. DOI: https://doi.org/10.1590/0103-1104201912019

26. Phillips RL, Kaufman A, Mold JW, Grumbach K, Vetter-Smith M, Berry A, et al. The primary care extension program: a catalyst for change. The Annals of Family Medicine 2013; 11(2): 173-178. PMID: 23508605 DOI: https://doi.org/10.1370/afm.1495 
27. Ferreira SMSP, Santos CML, Almeida CS, Moreira AVO, de Oliveira PA, Santos RS, et al. Ensino da saúde coletiva nos cursos de graduação: interdisciplinaridade e integração academia, serviço e comunidade em foco. Textura 2019; 13(21): 53-61. Portuguese. DOI: https://doi.org/10.22479/desenreg2019v13n21p53-61

28. da Silva TS, de Melo RO, Sodré MP, Moreira RDCR, do Nascimento Souza ZCS. A extensão universitária e a prevenção da violência obstétrica. Revista Ciência em Extensão 2017; 13(1): 176-189. Portuguese

29. Ministério da Saúde do Brasil, portaria n 2436, de 21 de Setembro de 2017 [Internet]. Aprova a Política Nacional de Atenção Básica, estabelecendo a revisão de diretrizes e normas para a organização da Atenção Básica, no âmbito do Sistema Único de Saúde (SUS). [mentioned as of December 12, 2020]. Available from: https://bvsms.saude.gov.br/bvs/saudelegis/gm/2017/prt2436_22_09_2017.html. Portuguese.

30. World Health Organization (WHO) [Internet]. Increasing access to health workers in remote and rural areas through improved retention: global policy recommendations, 2010 [mentioned as of May 12, 2020]. Available from: https://apps.who.int/iris/bitstream/ handle/10665/44369/9789241564014_eng.pdf;jsessionid=3351EC831F708FD6412A1C4C95A0ED6E?sequence=1

31. Borracci R, Arribalzaga EB, Couto JL, Dvorkin M, Guerrero RAA, Fernandez C, et al. Factors affecting the willingness to practice medicine in underserved areas: a survey of Argentinian medical students. Rural Remote Health 2015; 15(4): 3485.

32. Jones MP, Bushnell JA, Humphreys JS. Are rural placements positively associated with rural intentions in medical undergraduates? Medical Education 2014; 48(4): 405-416.

33. Wilkinson D, Laven G, Pratt N, Beilby J. Impact of undergraduate and postgraduate rural training, and medical school entry criteria on rural practice among Australian general practitioners: national study of 2414 doctors. Medical education 2003; 37(9): 809-814.

34. Grobler L, Marais BJ, Mabunda S. Interventions for increasing the proportion of health professionals practicing in rural and other underserved areas. Cochrane database of systematic reviews 2015; (6).

35. Edwards S, Da Silva ALS, Rapport FL, McKimm J, Williams R. Recruitment of doctors to work in 'our hinterland': first results from the Swansea Undergraduate Entry Program in Medicine. Rural and Remote Health 2015; 15: 3187.

36. Azer SA, Simmons D, Elliott SL. Rural training and the state of rural health services: effect of rural background on the perception and attitude of first-year medical students at the University of Melbourne. Australian Journal of Rural Health 2001; 9(4): 178-185.

37.Zhang L, Bossert T, Mahal A, Hu G, Guo Q, Liu Y. Attitudes towards primary care career in community health centers among medical students in China. BMC family practice 2016; 17(1): 75. 